\title{
Peran Umpan Balik Bagi Mahasiswa Kedokteran
}

\author{
Herlina I.S. Wungouw dan Diana V. Doda \\ Fakultas Kedokteran Universitas Sam Ratulangi Manado \\ Sulawesi Utara
}

\begin{abstract}
Background: Feedback is an important part in teaching and learning process that serve as a catalyst to enhance learners' achievement. In medical education, the importance of feedback has been recognized for learners at all level; undergraduate and postgraduate, in preclinical and clinical phases for more that twenty years.

Aim: This literature review wants to explore what is the effective feedback for medical students and what are the factors that affect giving feedback?

Discussion: The eighteen articles that fulfill the inclusion criteria bave been collected from several resources include Medline, Pubmed and ERIC databases. Characteristics of effective feedback bave been identified from those articles include positive, specific, private, well-timing, non-judgmental, interaction with sender, immediately given, from expert content, simple, and task oriented. While the factors affect giving feedback fall into four topics: the content of feedback, the method of delivery, sender credibility and training.
\end{abstract}

Keywords: effective feedback, characteristic, factors

\section{Abstrak}

Latar Belakang: Umpan balik merupakan bagian penting dalam proses yang dapat meningkatkan pencapaian kompetensi mahasiswa. Dalam pendidikan kedokteran, peran penting umpan balik sudah diketahui sejak lama baik ditingkat pendidikan sarjana dan paska sarjana serta pada tahap sebelum klinik dan tahap klinik.

Tujuan: Tulisan ini bertujuan untuk mengeksplorasi umpan balik efektif untuk mahasiswa kedokteran dan faktorfaktor yang mempengaruhi pemberian umpan balik.

Pembahasan: Sebanyak delapan belas artikel yang memenuhi kriteria inklusi berhasil dihimpun dari beberapa sumber "data base" elektronik seperti "Medline", "Pubmed” dan "Eric". Karakteristik umpan balik efektif yang teridentifikasi adalah umpan balik yang positif, spesifik, bersifat pribadi, tepat waktu, tidak menghakimi, ada interaksi dengan pemberi umpan balik, diberikan segera, dari sumber yang ahli, sederhana dan berorientasi pada tugas yang diberikan. Sementara faktor-faktor yang mempengaruhi pemberian umpan balik meliputi isi dari umpan balik, cara penyampaian, kredibilitas dari pemberi umpan balik dan pelatihan.

Kata Kunci: umpan balik efektif, karakteristik, faktor

\section{PENDAHULUAN}

Umpan balik menjadi bagian dari proses belajar mengajar dimana dapat berfungsi sebagai katalis untuk meningkatkan pencapaian mahasiswa melalui motivasi dan usaha. ${ }^{1}$ Paukert mengatakan bahwa memberikan umpan balik merupakan keterampilan mengajar yang penting sementara menerima umpan balik merupakan bagian yang penting dari belajar. ${ }^{2}$ Dengan umpan balik, kesalahan dapat dikoreksi dan kinerja yang baik dapat dipertahankan. ${ }^{3}$ Di samping itu pula, dengan ketidakhadiran umpan balik, mahasiswa mungkin tidak menerima informasi kunci yang diperlukan untuk meningkatkan kinerja mereka melalui perubahan perilaku. $^{2}$

Korespondensi : herlinawungouw@yahoo.com HP: 085240488633 
Umpan balik didefinisikan sebagai "informasi khusus yang diberikan pada orang yang belajar untuk merefleksi kinerja khususnya yang sudah dilakukan dan konsekuensi apa yang mungkin terjadi". ${ }^{3}$ Umpan balik merupakan sebuah teknik dimana pengajar menyediakan informasi bagi mahasiswa berkaitan dengan upaya belajar mereka dan mengarahkan mahasiswa untuk mengatasi kekurangan-kekurangan yang ada, dimana umpan balik ini dapat diberikan secara formal dan informal. ${ }^{4,5}$ Umpan balik berkaitan erat dengan penilaian formatif karena itu umpan balik sering disebut sebagai elemen penting untuk membimbing mahasiswa ke arah kinerja yang diharapkan. ${ }^{3,6}$

Secara mendasar umpan balik bertujuan untuk meningkatkan proses belajar mahasiswa. Lincon dkk mengemukakan bahwa dalam pendidikan kedokteran, umpan balik bertujuan untuk: (a) membuat mahasiswa tahu bagaimana interaksi mereka dengan pasien dan profesi kesehatan lainnya dalam lingkungan klinik, (b) meningkatkan kesadaran antara seorang dengan lainnya dalam hal tingkah laku ataupun perkataan, (c) menyediakan informasi melalui pengamatan yang efektif terhadap tingkah laku komunikasi interpersonal, (d) meningkatkan kesadaran terhadap perilaku seperti dalam strategi belajar, strategi modifikasi perilaku, dan keterampilan komunikasi, (e) menyediakan informasi faktual dan menilai sumber daya bagi dokter yunior maupun senior dalam pemeriksaan pasien, (f) membantu mahasiswa mengevaluasi kemajuan mereka dalam mencapai sasaran belajar saat rotasi di bagian klinik, (g) menyediakan komentar tertulis ataupun lisan tentang isi dan proses interaksi klinik, (h) menyediakan informasi khusus pada teknik tertentu dan keefektifannya pada target populasi, (i) memberikan umpan balik terkait prinsip-prinsip ilmiah dalam dunia kerja saat melakukan praktek. $^{?}$

Dalam pendidikan kedokteran, pentingnya umpan balik sudah dikenal sejak lama, kurang lebih sejak 20 tahun yang lalu di semua jenjang pendidikan, tahap sarjana dan pascasarjana, di fase pendidikan sebelum klinik dan di klinik. ${ }^{1}$ Umpan balik berperan sentral dalam pendidikan kedokteran dalam mendorong mahasisiwa belajar dan menjamin tercapainya standard pendidikan. ${ }^{8}$ Ada begitu banyak bukti yang mencatat keuntungan umpan balik yang meningkatkan dan memfasilitasi proses belajar di kedokteran. ${ }^{1,9,10}$ Mahasiswa yang menerima umpan balik melakukan keterampilan anamnesis yang lebih baik dibandingkan dengan mereka yang tidak mendapatkan umpan balik. Demikian halnya hasil penelitian Stiman dkk serta Sceived dkk bahwa mahasiswa yang menerima umpan balik lebih baik keterampilan komunikasinya. ${ }^{11}$

Meskipun efek menguntungkan dari umpan balik telah banyak dilaporkan, namun di Indonesia, pemberian umpan balik masih jarang diberikan oleh pendidik kedokteran bagi mahasiswa misalnya umpan balik yang berhubungan dengan hasil penilaian ataupun kinerja mahasiswa dalam praktek klinik. Disamping itu pula, pada beberapa institusi pendidikan yang sudah mempraktekkan pemberian umpan balik dalam proses belajar mengajar, banyak peneliti menemukan pendekatan yang kurang memuaskan terjadi dalam pemberian umpan balik ini. ${ }^{1,2,8}$ Umpan balik dinyatakan sebagai komponen yang sulit dilaksanakan dalam pembelajaran klinik dan kurang diamati dalam pertemuan klinik. ${ }^{2,8}$ Mahasiswa kedokteran tidak menerima umpan balik pada saat yang tepat dan staf akademik dinyatakan jelek dalam hal pemberian umpan balik segera setelah tatap muka, terutama enggan menyampaikan hal-hal negatif terhadap mahasiswa secara langsung. ${ }^{12}$

Dari penjelasan diatas, terlihat pentingnya melakukan eksplorasi lebih jauh tentang umpan balik ini, terutama bagi staf akademik untuk membantu meningkatkan proses belajar mahasiswa. Hal ini juga menimbulkan pertanyaan-pertanyaan yang membutuhkan jawaban seperti apa sesungguhnya umpan balik yang efektif dan faktor-faktor apa yang mempengaruhi pemberian umpan balik? Penulisan ini bersifat tinjauan pustaka untuk menjawab pertanyaan di atas.

\section{METODE}

Artikel-artikel yang digunakan dalam tinjauan ini didapatkan dari beberapa sumber data online seperti Medline, Pubmed dan ERIC. Terminologi yang digunakan saat melalukan pencarian artikel yaitu feedback, medical students, medical education, factors, effectiveness, effect dan benefit. Terminologi ini digunakan secara sendiri ataupun kombinasi.

Dua puluh artikel didapatkan dari hasil pencarian di database. Artikel ini kemudian diseleksi berdasarkan 
inklusi kriteria sebagai berikut: (a) merupakan artikel penelitian yang bersifat kualitatif maupun kuantitatif yang memenuhi kriteria sebagai artikel penelitian yang baik dengan menggunakan pedoman penilaian artikel berbobot dari Program Magister Pendidikan Kedokteran Sydney University (MDED 5002 Scholarship of Teaching on Medicine)..$^{13}$ (b) Penelitian dilakukan pada mahasiswa yang akan menjadi dokter atau dokter spesialis. (c) Artikel-artikel ini dipublikasikan sesudah tahun 1990. (d) Artikel-artikel ini ditulis dalam bahasa Inggris atau Indonesia. Sebagai hasilnya terdapat 18 artikel yang akan ditinjau pada penulisan ini.

\section{PEMBAHASAN}

Dari artikel-artikel yang sudah dilaporkan ternyata pemberian umpan balik banyak dilakukan pada tahap pendidikan klinik dimana mahasiswa mulai dikenalkan pada dunia kedokteran yang sesungguhnya. Memberikan dan menerima umpan balik merupakan pengalaman yang menantang dalam proses belajar mengajar.

\section{Karakteristik Umpan Balik Efektif}

Penelitian yang dilakukan menggunakan responden yang sangat bervariasi dengan menggunakan model penelitian kualitatif, kuantitatif ataupun gabungan kualitatif dan kuantitatif. Berikut ini adalah rincian hasil tinjauan tentang karakteristik dari umpan balik yang efektif. Sebuah penelitian kualitatif telah dilakukan untuk menjawab lima pertanyaan tentang umpan balik, salah satunya tentang apa sebenarnya umpan balik efektif itu. Hasil yang didapatkan tentang persepsi umpan balik yang efektif meliputi aspek (a) isi dari umpan balik sifatnya khusus dan tentang pengenalan yang positif. (b) cara penyampaian umpan tepat waktu, model tertulis atau lisan, secara pribadi dan tidak menghakimi, dan (c) interaksi dengan pemberi umpan balik seperti kesempatan untuk memberikan respon terhadap umpan balik atau konfirmasi lanjut tentang isi umpan balik. ${ }^{14}$ Colleti menunjukkan bahwa mahasiswa lebih suka untuk mendapatkan umpan balik segera sesudah penilaian dan umpan balik diberikan langsung oleh penilainya sesudah kinerja kepaniteraan klinik di bagian bedah. ${ }^{12}$ Penelitian lain tentang umpan balik telah dilakukan di lima institusi pendidikan dokter di Ontario yang menggunakan kurikulum belajar berdasarkan masalah. Hasilnya menunjukkan bahwa mahasiswa lebih senang menerima umpan balik yang bersifat perorangan dan merasa itu sangat bermanfaat bagi mereka. Budaya memberikan umpan balik sudah biasa mereka lakukan. ${ }^{15}$ Lagipula, dalam perspektif mahasiswa, umpan balik yang efektif sebaiknya diberikan segera atau paling lambat 2 minggu sesudah ujian tertulis, diberikan oleh dosen yang ahli, bersifat sederhana dan berkaitan langsung dengan tugas yang dikerjakan mahasiswa. ${ }^{6}$

\section{Faktor-faktor yang Mempengaruhi Pemberian Umpan Balik}

\section{Isi dari umpan balik}

Ketika mempelajari sistem penilaian baru di bangsal dibandingkan dengan sistem penilaian lama, Colleti menemukan bahwa staf akademik menemui kendala dalam menyampaikan umpan balik yang sifatnya negatif kepada mahasiswa saat berhadapan muka. ${ }^{12}$ Sebuah penelitian yang bersifat kualitatif yang menggunakan wawancara semi-terstruktur terungkap bahwa untuk pembelajaran tahap klinik supervisi dan umpan balik memainkan peranan penting. Dalam penelitian ini, umpan balik diberikan dalam sebuah program pelatihan tentang penilaian. Para peserta mengaku mereka mendapatkan informasi yang sangat sedikit tentang program ini. Penelitian ini juga mengungkapkan para penilai enggan memberikan umpan balik yang mengecewakan terkait mahasiswa yang tidak lulus atau dalam batas hampir tidak lulus. ${ }^{16}$

\section{Metode untuk memberikan umpan balik}

Gaya dan struktur pemberian umpan balik oleh dosen kedokteran sangat bervariasi. ${ }^{9}$ Beberapa metode pemberian umpan balik juga pernah dilaporkan dalam beberapa referensi yang bervariasi mulai dari bentuk tulisan, lisan dan elektronik.

\section{Umpan balik berbentuk tulisan}

Penelitian telah dilakukan pada Departemen Bedah Sekolah Kedokteran Southern Illinois USA. Mahasiswa yang menerima umpan balik tertulis dalam bentuk formulir lembar kemajuan mahasiswa menunjukkan mereka lebih mudah menyelesaikan tugas pembuatan status kardiovaskuler dan rencana penanganan 
dibandingkan dengan kelompok kontrol. ${ }^{17}$ Kartu laporan pertemuan (encounter card) yang digunakan di McMaster University telah dimodifikasi sesuai situasi di Texas University, USA. Dari kartu ini, mahasiswa kedokteran tahun ketiga menerima umpan balik dari staf dosen, teman dan residen selama kegiatan 12 minggu di bagian bedah. Tingkat kepuasan mahasiswa dengan proses umpan balik meningkat dan penggunaan kartu untuk umpan balik sangat bermanfaat dan dapat mengatasi masalah kurangnya umpan balik dalam proses belajar mengajar. $^{2}$

Umpan balik dengan menggunakan "prescription pads" digunakan sebagai metode sederhana bagi mahasiswa yang melakukan kegiatan kepaniteraan klinik. Selama kepaniteraan, mahasiswa dapat meminta dua umpan balik dari dosen yang berbeda setiap dua minggu. Mahasiswa memberikan ranking yang lebih tinggi dalam hal pemberian umpan balik dibandingkan dengan tahun sebelumnya yang belum menggunakan "prescription pads".

\section{Umpan balik lisan}

Brown and Knight mengemukakan bahwa umpan balik verbal dan diberikan secara individu adalah bentuk ideal untuk mahasiswa. ${ }^{18}$ Suatu penelitian terhadap empat puluh lima mahasiswa yunior yang sementara belajar keterampilan menjahit luka (suturing) secara random dibagi dalam tiga kelompok; kelompok A menerima umpan balik melalui komputer khusus yang dirancang untuk umpan balik, kelompok B menerima umpan balik seperti kelompok A ditambah nilai-nilai referensi pakar sementara kelompok $\mathrm{C}$ menerima umpan balik verbal dari pakar. Hasil penelitian dilaporkan semua kelompok menunjukkan peningkatan keterampilan menjahit luka dari pre-tes dan post tes, namun kelompok yang menerima umpan balik secara lisan menunjukkan retensi keterampilan yang lebih lama saat diuji beberapa waktu kemudian dibandingkan dengan kelompok yang lain sehingga disimpulkan bahwa umpan balik verbal dari pakar membantu retensi keterampilan menjahit luka mahasiswa. ${ }^{19}$ Sebuah penelitian lain dari Van Sickle dkk dilaporkan sehubungan dengan pemberian umpan balik. Mahasiswa yang melakukan laparaskopi dibagi dalam empat kelompok yaitu tanpa umpan balik, umpan balik dengan audio (bel), umpan balik berupa kata salah dari penguji dan kelompok yang menerima umpan balik bel dan kata salah dari penguji. Secara statistik, insisi yang benar secara signifikan dilakukan kelompok mahasiswa yang menerima umpan balik bel dan kata salah dari penguji. Tipe dan kualitas umpan balik mempengaruhi kinerja mahasiswa dalam melakukan laparaskopi. ${ }^{20}$

Suatu penelitian yang menarik dilakukan pada tahap pendidikan para residen yang berjumlah 68 orang. Hasil yang dilaporkan menunjukkan tidak ada perbedaan yang bermakna ditemukan pada kinerja residen dengan umpan balik tulisan dan lisan. Hal ini menekankan bahwa aspek lain dari umpan balik menjadi penting artinya seperti frekwensi pemberian umpan balik. ${ }^{9}$ Hasil ini juga mengakibatkan belum adanya kesimpulan tentang metode terbaik dalam menyampaikan umpan balik.

\section{Umpan balik yang diberikan secara elektronik}

Umpan balik dalam bentuk sesi video telah diteliti beberapa kali. ${ }^{16,21}$ Paul dkk menemukan bahwa umpan balik dengan menggunakan video sangat bermanfaat saat mengajarkan keterampilan medis. Delapan puluh lima persen dari dua puluh tujuh mahasiswa yang menerima umpan balik dari instruktur dan teman ingin mendapatkan lebih dari satu kali umpan balik saat konsultasi dan melihat rekaman kinerja mereka. Sebagai tambahan, mahasiswa dapat mengenali kelemahan dan kekuatan mereka. Tidak adanya informasi mengenai cara rekrutmen dan jumlah partisipan yang diteliti mengakibatkan sulitnya mengambil kesimpulan dari penelitian ini. ${ }^{21}$ Boehler $\mathrm{dkk}^{1}$ mengemukakan bahwa kinerja mahasiswa yang direkam dan menerima umpan balik meningkat dibandingkan dengan kelompok yang tidak menerima umpan balik. Umpan balik membantu mahasiswa dalam belajar dan bukan sekedar rasa puas. Baru-baru ini, sebuah program pendidikan on line dikembangkan sebagai sarana dimana residen menyediakan umpan balik secara mingguan kepada 149 mahasiswa. Sembilan puluh dua mahasiswa di kelompok intervensi mengakui umpan balik dari residen sangat membantu proses belajar mahasiswa. Program ini berhasil meningkatkan frekwensi dan kualitas umpan balik. ${ }^{22}$ Hasil penelitian ini memperkaya metode pemberian umpan balik dengan menggunakan alat elektronik untuk mahasiswa kedokteran.

Namun ada hal yang perlu juga diperhatikan terkait pemberian umpan balik dengan bantuan video. Stres 
mahasiswa saat dilakukan perekaman video bertambah saat melakukan keterampilan klinik dilaporkan oleh penelitian di University of Bergen, Norway. Saat diskusi kelompok terfokus (FGD) mahasiswa begitu gugup sebelum rekaman video untuk konsultasi dan umpan balik. Sekalipun hasilnya tetap menunjukkan aspek positif dari rekaman video untuk umpan balik, pendidik tetap perlu memperhatikan ketakutan dan kecemasan mahasiswa yang mengakibatkan berkurangnya percaya diri. ${ }^{23}$ Menyediakan dukungan dan menambah keyakinan untuk mahasiswa akan sangat bermanfaat bila akan memberikan umpan balik secara elektronik seperti rekaman video.

\section{Sumber dari Umpan Balik}

Kredibilitas pemberi umpan balik merupakan salah satu faktor yang mempengaruhi cara penerimaan umpan balik. Umpan balik dari seorang yang belum berpengalaman cenderung diabaikan oleh mahasiswa. ${ }^{14}$ Ada empat kategori yang dihubungkan dengan kredibilitas pemberi umpan balik yaitu: (a) persepsi penerima umpan balik terhadap karakteristik pemberi umpan balik seperti kurangnya rasa percaya dan hormat, kurangnya tingkat pengetahuan, kurangnya pengalaman; (b) pengamatan penerima umpan balik terhadap tingkah laku pemberi umpan balik misalnya kurangnya perhatian, menjaga jarak, jeleknya keterampilan hubungan interpersonal; (c) isi dari umpan balik seperti menitikberatkan umpan balik pada hal yang kurang perlu, atau umpan balik yang tidak sesuai dengan kenyataan; (d) metode penyampaian umpan balik seperti bersifat menghakimi, diberikan dalam konteks kelompok. Sebuah penelitian dari Poulos dkk mengungkapkan bahwa persepsi mahasiswa terhadap kegunaan umpan balik memiliki hubungan erat dengan kredibilitas dosen yang memberikan umpan balik. ${ }^{10}$

\section{Pelatihan}

Fernando N, Cleland J, Mc Kenzie H, Cassar K, secara retrospektif mengeksplorasi faktor yang menentukan ketepatan umpan balik bagi mahasiswa kedokteran sesudah penilaian "mini-clinical evaluation exercise" (MiniCEX). Mereka mengidentifikasi kurangnya pengalaman penilai, lebih khusus penilai yang "non akademik" mempengaruhi proses pemberian umpan balik, sehingga pelatihan pemberi umpan balik sangat diperlukan. ${ }^{24}$ Walaupun penelitian ini dilakukan hanya pada satu kondisi klinik sehingga agak sulit untuk menarik kesimpulan umum, hasil penelitian ini memberikan gambaran tentang kurangnya umpan balik dari dosen bagi mahasiswa kedokteran secara tidak langsung juga disebabkan oleh kurangnya pelatihan tentang cara pemberian umpan balik.

Sebuah penelitian dengan metode campuran (metode kualitatif dan kuantitatif) menggunakan survei, diskusi kelompok terarah dan diskusi sesudah survei telah dilakukan pada mahasiswa tahap akademik dan dosen Universitas Kedokteran Internasional di Malaysia. Penelitian ini menegaskan perlunya pelatihan bagi para pemberi umpan balik dan mengusulkan pelatihan ini menjadi aktifitas rutin untuk pengembangan sumber daya manusia di fakultas. ${ }^{6}$

Hasil penelitian dari artikel artikel yang digunakan dalam tinjauan pustaka ini menunjukkan bahwa umpan balik yang efektif sesuai dengan artikel non penelitian yang dipublikasikan lebih dahulu. ${ }^{3,5}$ Karakteristik dari umpan balik efektif yang telah diidentifikasi sebelumnya adalah: (a) waktu yang tepat yang berarti umpan balik menjadi bagian dari kegiatan rutin harian, dengan waktu yang disepakati bersama antara pemberi dan penerima umpan balik dan dilakukan dekat dengan kegiatan yang mendasari umpan balik itu diberikan (b) didasarkan pada data atau observasi langsung pemberi umpan balik (c) menggunakan bahasa yang tidak menghakimi. (d) didasarkan pada hal spesifik dan bukan umpan balik umum (e) difokuskan pada kegiatan yang dilakukan mahasiswa dan bukan pada kepribadiannya (f) mahasiswa diberikan kesempatan sebelumnya untuk mengomentari kinerja mereka sendiri. ${ }^{5}$ Agar bisa memberikan umpan balik dengan sukses, Ende memberikan petunjuk untuk pendidik klinik seperti pada Tabel $1 .^{3}$ 
Pedoman Pemberian Umpan Balik

Umpan balik dilakukan atas kesepakatan dosen dan peserta didik

Umpan balik harus tepat waktu dan sesuai

Umpan balik harus berdasar fakta

Umpan balik harus diatur jumlahnya dan dibatasi untuk perilaku yang dapat diperbaiki

Umpan balik harus disampaikan dengan bahasa deskriptif, tidak menghakimi

Umpan balik harus bersifat kinerja yang spesifik bukan umum

Umpan balik harus memberikan data subyektif

Umpan balik ditujukan untuk suatu keputusan dan tindakan, bukan keinginan atau interpretasi

Gambar 1. Pedoman pemberian umpan balik ${ }^{3}$

Tabel 1. Umpan balik yang efektif

\begin{tabular}{|c|c|c|}
\hline Penulis & Seting & Identifikasi Umpan Balik Efektif \\
\hline Bing-You ct al, 1997 & $\begin{array}{l}12 \text { mahasiswa pascasarjana, wawancara } \\
\text { semi terstruktur }\end{array}$ & $\begin{array}{l}\text { positif, spcsifik, pribadi, waktunya scsuai, } \\
\text { tidak menghakimi, interaksi dengan } \\
\text { pemberi umpan balik }\end{array}$ \\
\hline Colleti,2000 & $\begin{array}{l}24 \text { mahasiswa tahun ketiga, metode } \\
\text { kombinasi }\end{array}$ & umpan balik langsung \\
\hline Parikh et al, 2001 & $\begin{array}{l}103 \text { mahasiswa tingkat akhir di } 5 \text { fakultas } \\
\text { kedokteran, menggunakan kuesioner }\end{array}$ & umpan balik individual \\
\hline Perera et al,2008 & $\begin{array}{l}407 \text { mahasiswa pre klinik dan } 126 \text { dosen, } \\
\text { kuesioner, } \\
\text { focus group and post survey discussion }\end{array}$ & $\begin{array}{l}\text { umpan balik segera diberikan, dari } \\
\text { pakarnya, simpel dan berorientasi pada } \\
\text { penugasan }\end{array}$ \\
\hline
\end{tabular}

Faktor-faktor yang mempengaruhi pemberian umpan balik telah diidentifikasi terutama dari beberapa sumber terutama dari penelitian kualitatif yang memberi peluang untuk pertanyaan terbuka dan setengah terstruktur. Disamping itu, Sachdeva ${ }^{4}$ juga mengemukakan keterbatas-an waktu dosen dan kurangnya informasi tentang kinerja mahasiswa sebagai faktor tambahan yang mempengaruhi pemberian umpan balik. Literatur menunjukkan umpan balik dalam bentuk tulisan tetap populer dan paling banyak digunakan. ${ }^{18}$ Meskipun umpan balik lisan dikatakan lebih baik dari metode yang lain, tidak cukup bukti yang didapatkan untuk menunjang pendapat diatas. Setiap metode pemberian umpan balik dapat digunakan dengan pertimbanganpertimbangan tertentu sesuai situasi dan kondisi yang ada.

Sumber umpan balik juga memainkan peran penting dalam pemberian umpan balik. Hesket mengemukakan bahwa umpan balik efektif dipengaruhi oleh tiga faktor yaitu kredibilitas pemberi umpan balik, pesan yang disampaikan dalam umpan balik dan kesiapan penerima untuk merespon umpan balik. ${ }^{5}$ Pentingnya kredibilitas pemberi umpan balik juga berlaku di tahap pendidikan profesi. Dalam tinjauan yang dilakukan oleh Velosky $\mathrm{dkk}$ ternyata tema yang konsisten tentang efek dari umpan balik terhadap kinerja mahasiswa dipengaruhi oleh pemberi umpan balik. ${ }^{2,4}$

Perspektif ketidakpuasan mahasiswa kedokteran sehubungan dengan tidak cukupnya umpan balik yang mereka terima selama proses belajar telah dilaporkan., ${ }^{1,3}$ Para dosen seharusnya memiliki keterampilan dan pengetahuan yang memadai tentang cara menyampaikan umpan balik yang efektif yang dapat diupayakan melalui program pengembangan fakultas. ${ }^{4}$ Pelatihan ini telah dikenali sebagai bagian penting bagi dosen kedokteran agar dapat memberikan umpan balik sebagaimana dikemukan oleh Hewson dalam pengalaman pribadinya sebagai pendidik klinik. Hewson menekankan bahwa 
kebutuhan terbesar dari pendidik klinik yaitu belajar bagaimana menyediakan umpan balik yang efektif. ${ }^{8}$ Isu yang sama terungkap dari sebuah "workshop" keterampilan pendidik klinik, banyak dosen baru yang memberikan skor tertinggi pada sesi pemberian umpan balik sebagai sesi terpopuler yang menandakan pentingnya pelatihan pemberian umpan balik bagi dosen kedokteran. ${ }^{25}$

\section{KESIMPULAN}

Umpan balik adalah hal esensial untuk meningkatkan pembelajaran mahasiswa. Beberapa karakteristik dari umpan balik yang efektif telah diidentifikasi yaitu positif, khusus, personal, waktu tepat, tidak menghakimi, ada interaksi dengan pemberi umpan balik, sederhana, berorientasi pada tugas yang diberikan, dan dari pakarnya. Sementara faktor yang mempengaruhi pemberian umpan balik digolongkan dalam empat topik yaitu isi umpan balik, metode penyampaian umpan balik, kredibilitas pemberi umpan balik dan pelatihan.

Telaah artikel ini didasari pada artikel yang sesuai kriteria inklusi sehingga tidak menutup kemungkinan masih adanya hal-hal lain terkait umpan balik yang perlu dieksplorasi lebih lanjut.

\section{DAFTAR PUSTAKA}

1. Boehler ML, Rogers DA, Schwind CJ, Mayforth R, Quin J, Williams RG, et al. An investigation of medical student reactions to feedback: a randomized controlled trial. Medical Education. 2006;40:746-9.

2. Paukert JL, Richards ML, Olney C. An encounter card system for increasing feedback to students. The American Journal of Surgery. 2002;183:300-4.

3. Ende J. Feedback in clinical medical education. JAMA. 1983;250:777-81.

4. Sachdeva AK. Use of efective feedback to facilitate adult learning. J Cancer Educ. 1996;11:106-8.

5. Hesketh EA, Laidlaw JM. Developing the instinct: feedback. Medical Teacher. 2002;24(3):245-8.

6. Perera J, Lee N, Win K, Perera J, Wijesuriya L. Formative feedback to students: the mismatch between faculty perceptions and student expectations. Medical Teacher. 2008;30:395-9.

7. Lincoln M, Carmody D, Maloney D. Professional development of students and clinical educators. In: McAllister L, Lincoln M, McLeod S, Maloney D, editors. Facilitating Learning in Clinical Settings. Cheltenham: Stanley Thornes, 1997:87-92.
8. Hewson MG, Little ML. Giving feedback in medical education verification of recommended techniques. J Gen Intern Med. 1998;13:111-6.

9. Elnicki DM, Layne RD, Ogden PE, Morris DK. Oral versus written feedback in medical clinic. J Gen Intern Med. 1998;13:155-8.

10. Poulos A, Mahony MJ. Effectiveness of feedback: the students' perspective. assessment and evaluation in higher education. 2008; 33(2):143-54.

11. Prystowsky JB, Da Rosa DA. A learning prescription permits feedback on feedback. The American Journal of Surgery. 2003;185:264-7.

12. Colletti LM. Difficulty with negative feedback: face to face evaluation of Junior medical student clinical kinerjance results in grade inflation. Journal of Surgical Research. 2000;90:82-7.

13. Sydney University. Medical education course MDED 5002 scholarship of teaching in medicine-guideline for literature review. Sidney: Sydney University, 2008.

14. Bing-You RG, Paterson J, Levine MA. Feedback falling on deaf ears: residents' receptivity to feedback tempered by sender credibility. Medical Teacher. 1997;19(1):40-4

15. Parikh A, McReelis KM, Hodges B. Student feedback in problem based learning: a survey of 103 final year students across five Ontario medical school. Medical Education. 2001;35:632-6.

16. Daelmans HEM, Overmeer RM, Hem-Stokroos HHVD, Scherpbier AJJA, Stehouwer CD, Vleuten CPMVD. In training assessment: qualitative study of efects on supervision and feedback in an undergraduate clinical rotation. Medical Education. 2006;40:51-8.

17. Niehaus AH, York NL, DaRosa DA, Markwell SJ, Folse R. The effect of feedback on students' abilities to write daily progress notes. Teaching and Learning in Medicine. 1995;7(2):92-4.

18. Brown S, Knight P. Assessing learners in higher education. London: Kogan Page; 1994.

19. Porte MC, Xeroulis G, Reznick RK, Dubrowski A. Verbal feedback from an expert is more effective than self-accessed feedback about motion efficiency in learning new surgical skills. The American Journal of Surgery. 2007;193:105-10.

20. Van Sickle KR, Gallagher AG, Smith CD. The effect of escalating feedback on the acquisition of psychomotor skills for laparoscopy. Surg Endosc. 2007;21:220-4.

21. Paul S, Dawson KP, Lanphear JH, Cheema MY. Video recording feedback: a feasible and effective approach to teaching history-taking and physical examination skills in undergraduate paediatric medicine. Medical Education. 1998;32:332-6. 
22. Matzie KA, Kerfoot P, Hafler JP, Breen WM. Spaced education improves the feedback that surgical residents give to medical students: a randomised trial. The American Journal of Surgery. 2009;197(2):252257.

23. Nilsen S, Baerheim A. Feedback on video recorded consultations in medical teaching: why students loathe and love it - a focus-group based qualitative study. Medical Education. 2005;5:1-6.
24. Fernando N, Cleland J, McKenzie H, Cassar K. Identifying the factors that determine feedback given to undergraduate medical students following formative mini-CEX assessments. Medical Education. 2008;42:89-95.

25. Steinert Y, Lawn N, Handfield-Jones R, Nasmith L, Lussier D, Levitht C. Orientation for new teachers: workshop on clinical teaching skills. Canadian Family Physician. 1995;41:79-85. 